\title{
The "Glocal" Dynamics of Construction Labor and Digital Architecture: Preston Scott Cohen's Addition to the Tel Aviv Museum as Case Study
}

\author{
Roy Kozlovsky \\ Azrieli School of Architecture, Tel Aviv University, Tel Aviv, Israel \\ Email: rkozlov@post.tau.ac.il
}

Received 2 March 2015; accepted 22 June 2015; published 25 June 2015

Copyright (C) 2015 by author and Scientific Research Publishing Inc.

This work is licensed under the Creative Commons Attribution International License (CC BY).

http://creativecommons.org/licenses/by/4.0/

(c) (7) Open Access

\begin{abstract}
Globalization and technological change are transforming the ways in which buildings are being designed and built. An overlooked aspect of this development is its impact on construction labor, and the significance of labor for assessing the work of architecture. The paper draws upon the sociological concept of the "glocal" to analyse the construction site as the product of the tension between global and local conditions of architectural production and consumption. The construction of Preston Scott Cohen's 2010 Tel Aviv Museum Addition serves as its case study for theorizing the "glocal" dynamics of digital architecture, building technology and construction labor. This methodological approach highlights the role of migrant guest workers and technological transfer in contemporary construction culture. To realize with precision the complex design under local constraints, the contractor developed a hybrid work process that interspersed labor saving automated manufacturing techniques with artisanal, skilled construction work. In addition, workers and contractors exercised a high level of control over the pace and method of construction, and devised building solutions which improved upon the architect's design. In conclusion, the paper argues that construction activity differs from broader trends in manufacturing due to the selfreflexivity of architectural design to its condition of production, but that at the same time, this critical capacity is enabled by the globalization of construction labor.
\end{abstract}

\section{Keywords}

History of Construction Technology, Digital Architecture, Labor Policy, Globalization 


\section{Introduction: The Labor of Construction and Digital Architecture}

Computational technology is transforming the ways in which buildings are designed and built, and how the relationship between these two aspects of architectural production is theorized. Frank Gehry’s Bilbao Guggenheim Museum (1997) provided an important precedent for theorizing the reciprocal relationship between "virtual" design and "material" construction. The architects pioneered the architectural usage of CATIA, a software program developed by the aerospace industry, to realize with precision and economy the building's complex, irregular forms; in addition, they modified the manufacturing process of titanium alloy sheets, to endow the building's animated surface with fabric-like tactility [1] [2]. Thus the discussion of the design and construction of this building was framed by two discourses: the debate over the epistemic status of virtual architecture in relation to qualities associated with traditional architectural production, such as materiality, tectonics, or craftsmanship; and the dynamics of "technological transfer" from one field of knowledge to another as an agent for architectural innovation [3]. The geographical context of the Bilbao commission suggests that the discussion of this concept needs to be broadened to include transfers across national and cultural boundaries, as the global reach of digital architecture has had the effect of bringing into contact different cultures of design and construction.

One of the consequences of this encounter is that it draws attention to the predicament of construction labor. To take the example of Zaha Hadid, the discussion of her Guangzhou opera house, completed in 2010, included an assessment of the capability of the local construction industry and its workforce to meet the technical challenges posed by the exuberant design [4]; Another project by Hadid, the Al Wakrah stadium in Qatar, has drawn condemnation over the employment conditions of migrant construction workers in the Gulf States even before work on site had begun [5]. In these two cases, the subject of labor is raised in a negative manner. First, it appears as a constraint to the realization of the work of architecture and as a barrier to the flow of knowledge and technology from center to periphery. Secondly, interest in construction labor is related to a broader critique of the impact of globalization on labor conditions and human rights in developing countries, and is used to criticize "formalist" digital architecture as being socially irresponsible.

These interpretive approaches, I argue, designate construction labor as subservient to architectural authorship, thus denying it of agency and criticality; in addition, technological transfer is assumed to be unidirectional, thus overlooking the possibility of exchange of knowledge and skills across the technical division of labor. The aim of this essay is to present a critical approach for interpreting buildings as works of architecture by examining them as sites of labor. The proposed methodology analyses construction activity as a process that brings together materials, techniques, and labor to produce value; it then examines how the work invested in construction is endowed with architectural meaning that contributes to the cultural value of the building. These two aspects are examined historically, in relation to the modes of production and consumption that characterize globalization.

Preston Scott Cohen's 2010 Herta and Paul Amir Building Addition to the Tel Aviv Museum (Figure 1) will
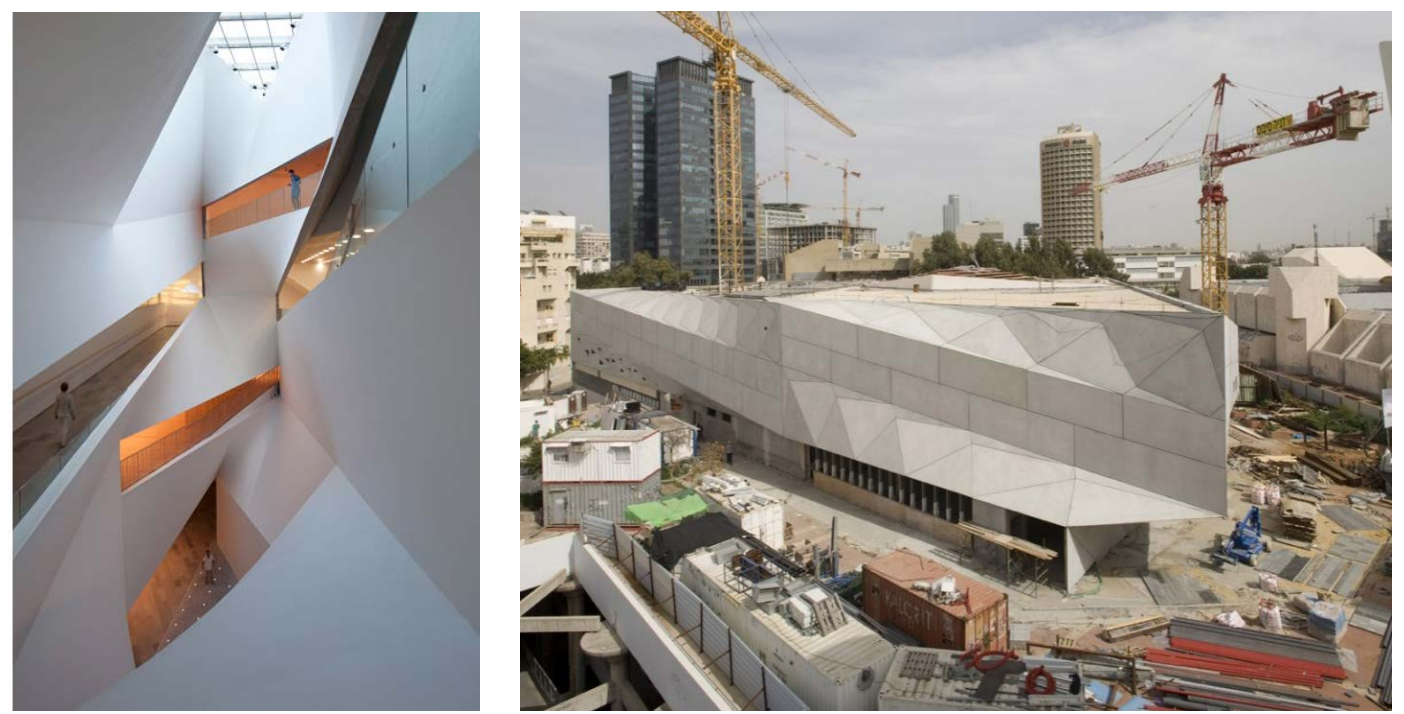

Figure 1. The Herta and Paul Amir Building: The lightfall, left; the concrete panel facade, right. 
serve as a case study for applying this approach. The discussion of the building included from the very start an account of the construction process that was developed for realizing three distinct elements of its computer generated design: the cast-in-place concrete atrium (known as the "lightfall”); the building's steel-frame structure; and its curvilinear façade made of prefabricated concrete panels. Not unlike other modes of representation, architectural accounts of the process of construction serve a rhetorical function, to communicate the architect's position towards modernistic principles such as the ethics of truth to materials (the belief that materials should be employed only in accordance with their capacities) or structural rationalism (a theory that stipulates that the art-form arises out of the method of construction). In this respect, the photographic representation of the museum's construction process reiterates Antoine Picon's assertion [3] that digital architecture is not oblivious to the material realities of construction, but rather establishes a dynamic rapport with it by merging computerized design and manual craftsmanship into a higher synthesis of virtual, fluid form and concrete, sensuous materiality.

This essay seeks to expand the discussion of the construction process of the museum beyond the debate over digital technology by introducing the subject of labor into the discussion of the relationship between design and execution. The implementation of the building's experimental design required the local contractor to make many adjustments, among them developing new building techniques, importing skilled workers from abroad, and devising modifications to the original design. In addition, it will be shown that the design itself was intended to showcase the skills of construction labor as a meaningful, even critical aspect of the building, and that it was reflexive of the local, historical meaning given to building materials and the labor invested in them. This dynamics is not captured by current interpretations of digital architecture that dissociate the discussion of technology from its entanglement with labor and locality. By positioning the museum's construction process within the dynamic tension between global processes and local conditions of production and consumption, the construction site is interpreted as a site of conflict and exchange, rather than as a means for achieving an architectural end.

The main contribution of the paper to the history of construction is to study building activity through the concept of the "glocal”, a term that brings into analysis the interrelationship between local and global processes and histories. The following section presents the theoretical considerations that guide the analysis; afterwards, the construction process of the museum is examined in relation to local conditions of labor as they are affected by global processes; in conclusion, it reassess the construction site as a critical component of the work of architecture.

\section{Globalization, Construction Labor, and Architectural Criticism}

\subsection{The Glocal}

The concept of the glocal serves to theorize the labor invested in construction within the broader context of globalization. The term was developed as a critique of an earlier interpretation of globalization as a homogenous process of modernization at the expense of local cultures [6]. As Castells [7] has shown in his work on the informational economy, globalization impacts each country in a different manner according to its specific political structure, economic policy, labor arrangements, and cultural traditions. The glocal promotes a dialectical understanding of globalization in which the local is both integrated and differentiated from the global: in fact, locality itself is seen as being actively produced by the process of globalization [6]. In the case of digital architecture, the concept of the glocal allows to disengage it from overreaching, linear narratives of technological progress, by focusing on the heterogeneous context of its production and consumption.

The consumption of digital architecture is conceptualized through the notion of mediascape. Arjun rai [8] coined the term to account for the work of the imagination as a constitutive feature of modern subjectivity. Global consciousness is shaped by the transnational flows of narratives and images that transform everyday worldviews and ways of self-imagining beyond traditional sources of authority such as the family or the state. The concept of mediascape is especially relevant for analyzing the contemporary building type of the museum. The Guggenheim Museum’s spectacular design, for example, succeeded in transforming Bilbao’s global image, leading one critic to characterize it as a "brandscape" [9].

The framework of the glocal suggests that the architectural imagery of the museum is neither homogenous nor universal: cities commission internationally renowned architects (among them Gehry and Hadid) to design unique museums that incorporate local cultural features to project an identity that can partake in the multi-cultural, pluralistic ideal of global society. Cohen's building, as will be discussed shortly, is self-reflexive in respect to the museum's branding function within the mediascape of globalization. 


\subsection{Construction Labor and Globalization}

The framework of the glocal is conductive to the understanding of how globalization affects construction labor as a meaningful element of the work of architecture. This theme is developed by examining labor conditions in the building sector in relation to broader trends in the organization of work brought about by globalization and technological change [7]. As its name implies, globalization has a spatial dimension: worldwide interconnectivity and competition across national boundaries compel businesses to increase efficiency and flexibility while reducing costs. Firms reduce labor costs through automation or relocation of jobs to lower wage labor markets. To increase flexibility, large, hierarchical corporations tend to restructure into lean, decentralized networks of extended subcontracting chains on the basis of a project; their workforce is increasingly self-employed or temporary, in contrast with the permanent employment model promoted by welfare state capitalism [7].

An important framework for assessing the impact of globalization on work is the discourse of skills. Braverman's deskilling theory [10] stipulated that under capitalist relations of production, employersseek to reduce labor costs by fragmenting the work process into routine tasks that could be performed by unskilled labor. In this interpretive framework, the aim of technological innovation in manufacturing is not only to increase productivity, but also to reduce the skills needed to perform the job in order to weaken the autonomy and bargaining power of labor. Knowledge, skills and control of the work processes are transferred from workers to management. The social byproduct of this process is the polarization of society into a majority of unskilled, expandable and alienated workers, and a specialized, committed managerial and technical elite.

The construction industry and its employment structure do not fully correspond with these general tendencies. As a non-tradable good, construction cannot be entirely outsourced to lower cost labor markets, as at least part of the work has to be performed on site. Due to the economic importance of the domestic construction sector as an employer of blue collar workers, political constraints often work against importation of cheaper foreign workers at the expense of citizens [11]. Even in cases in which barriers to international competition are lowered, such as for large scale, capital intensive infrastructural projects, multinational corporations are often compelled to form joint partnerships with local firms to facilitate technological transfer and protect local employment. In addition, the construction sector has been observed to be relatively resistant to the general tendency to raise productivity and efficiency by using capital-intensive, labor saving manufacturing techniques such as robotics, since many building tasks cannot be automated or even mechanized. Consequently, contemporary construction workplaces share many of the attributes associated with pre-industrial forms of labour [12].

\subsection{Architectural Theory and Labor}

Yet there is another factor that plays a part in differentiating construction from broader trends in manufacturing: the self-reflexivity of the architectural discipline in respect to the condition of its production. Architects may prescribe building techniques that are asynchronous with dominant labour practices. For example, they may specify a craft intensive, inefficient work process as a critique of capitalism's utilitarian and instrumental worldview; or conversely, they may promote mechanization and prefabrication even when local conditions render traditional methods more economical, in order to symbolize progress. This is because the conscious differentiation of architectural labor from the general mode of labour is fundamental to the performativity of the modern work of architecture as an object of reflection and critique.

The emergence of architectural modernity is historically tied with the practice of endowing construction labor with critical meaning. Movements such as Arts and Crafts and Brutalism promoted manual building techniques to counter what they considered to be the pernicious effect of industrialization and deskilling on workers and culture alike. For John Ruskin [13], the time, devotion and skills invested in the process of construction informed the aesthetic appreciation of the work of art as a product of free, non-alienated human labor. William Morris in turn sought to mitigate the division of labor between designers, makers and the public by socializing manufacturing into guild-like workshops.

In contrast, modern architects ascribing to functionalism consciously sought to reduce the reliance on traditional building trades by appropriating industrial methods of mass production and fabrication, and by eliminating details such as ornament that depended on craftsmanship. As Bruno Reichlin [14] pointed out, the attempt of architects to apply objective scientific principles to the design process manifested itself in a wholesale shift from object-based aesthetics to the poetics of the process of construction.

The architectural Avant-garde has approached the issue of artistic skills ideologically, as part of their critique of 
authorship. In traditional notions of art, the artist's highly skilled, manual manipulation of materials is seen as an expression of the authentic subjectivity of the individual artist [15]. Constructivism intentionally dispersed authorship by utilizing non-artistic modes of labor such as factory production, while Dadaartists self-consciously deskilled artistic production altogether by appropriating "readymade" objects.

Following the "linguistic turn", post modernism shifted the emphasis from the process of making works of art to their communicative and symbolic function, with the result that buildings assumed the status of a signifier rather than that of a material object [16]. It is only recently that the process of making buildings reentered architectural criticism. Kenneth Frampton [17] constituted the tectonic dimension of construction as a poetic, ontological act. Edward Ford's analysis of modern detailing brought into discussion the agency and latitude of draftsmen, craftsmen and contractors in making building decisions at the stage of execution [18]. The discussion of digital architecture corresponds with this renewed interest in construction. Publications such as Digital Tectonics and The Future Details of Architecture argue for the potential of customization and direct fabrication technics to establish a creative engagement across the technical division of labor between architects, manufacturers and construction workers.

Seen historically, then, construction labor played an important role in constituting architectural modernity, either through the debates surrounding craft and mechanization, the discourse of authorship and skills, or the ontological status of buildings as things. It adds another layer of meaning for analyzing the construction process in relation to globalization. The next two sections examine the construction process of the museum in relation to the glocal mode of production and consumption of the work of architecture.

\section{Consuming Complex Geometry}

\subsection{Complex Geometry and Architectural Labor}

Preston Scott Cohen, the architect who won the competition for designing the museum extension in 2002, was until then known primarily for hisunrealized Torus House (Figure 2). The project, which was exhibited at the Museum of Modern Art in 1999, displays Cohen's experimental approach to design in which form is generated by merging two different projection techniques used by architects: point perspective for representing the spatial properties of the object, and stereotomic projection for instructing the cutting of stone [19].

Cohen's position on architectural agency is critical of authorial will. The formal complexity and strangeness of his designs is justified as a by-product of the struggle to reconcile architectural codes and norms with the complex needs of the site and the program, rather than as an expression of individual subjectivity or a quest for novelty. For the Torus House, the architect self-consciously introduced a "problem with geometrical consequences": combining the traditional typology of the house with non-Euclidian geometry that blurs the distinction between vertical walls and horizontal floors [19].

As the Tel Aviv commission proved to be his first major realized commission, it serves as a test case for Cohen's theoretical speculations. The addition is situated on a triangular lot adjacent to the old museum building that was completed in 1971. The torqued, computer generated form of the building is a result of the tension between the triangular lot and the rectangular shape of the exhibition spaces inside; another "problem" developed by the
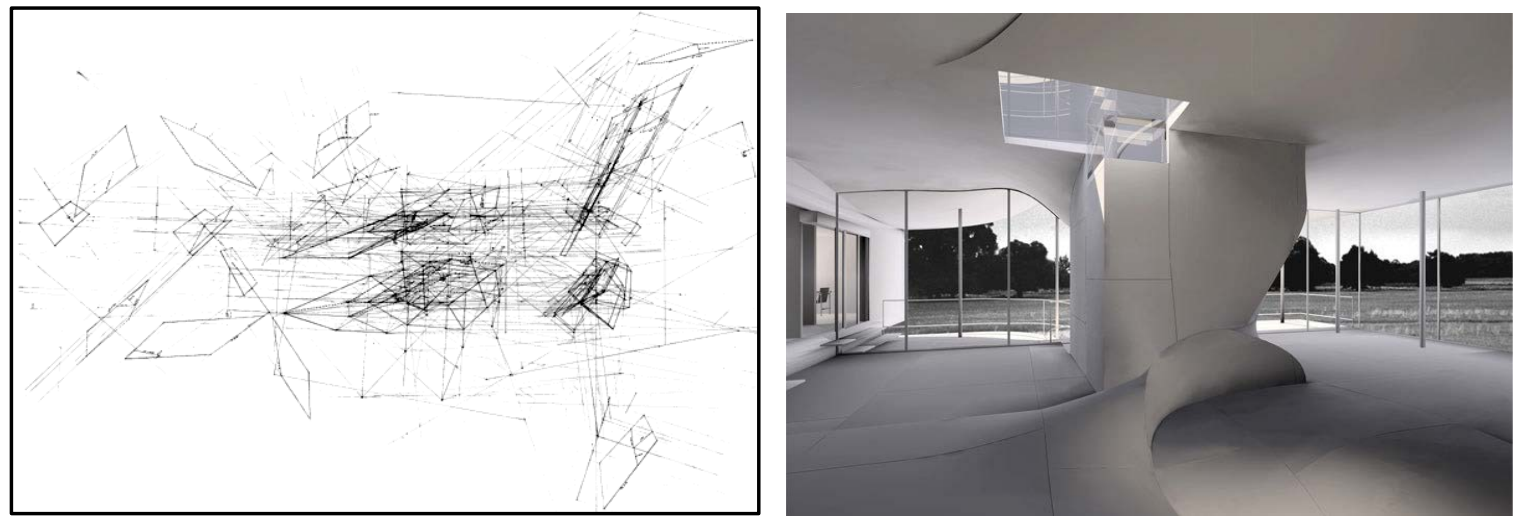

Figure 2. Preston Scott Cohen: Stereotomic Permutations (1994), left. The interior of the Torus House (1998), right. 
architect is the conflict between the demand that the museum building will be an architectural spectacle in its own right, and the needs of display, which requires neutral spaces that do not distract the spectator's attention from the exhibited artwork. The inner atrium's convoluted form was produced by rotating the rectangular spaces to correspond to the two entry routs to the building that meet in an oblique angle (Figure 3). This animated formal process is reiterated in a more muted fashion in the building's envelop, which gently folds and twists from the roof downwards until it meets the straight triangular boundary of the lot.

\subsection{Local Meaning of Design}

That Cohen's theoretical research into projective geometry was first realized in Tel Aviv is essential for the analysis of the building in terms of the dynamics of the glocal. According to the architect [20], his competition entry was selected because "only foreignness was capable of detaching this new building from its Israeli context and of placing it within the context of contemporary international architecture-and by extension, of introducing Israeli art to the international art world." The avant-garde design was consciously embraced by the Israeli client to accumulate the cultural capital for branding Tel Aviv as a global city, following the exemplary success of the Guggenheim Museum in transforming Bilbao's image through a capital intensive architectural investment.

Yetthe logic of the glocal also entails that the building would project a desired local identity to the world; this was done by inscribing Israel's architectural heritage into a universal narrative. An Architectural Record review of the building, titled “A New Spin to the White City" [21], associated Cohen's novel design with "the city's history of embracing radical leaps in Modernism”, a direct reference to the designation of Tel Aviv's modernist urban core (called the White City) as a World Heritage Site in 2003. The city's modernist heritage, together with Erich Mendelsohn's work in Mandatory Palestine, has since been included in major architectural surveys [22] [23] as examples of regional adaptations of modernism. Cohen's design self-consciously reinforces this glocal narrative.

Another local reference point of the design is the original museum building, considered a masterpiece of Israeli Brutalist architecture. Designed by the Israeli architects Yashar and Eytan, the old building (Figure 4) is
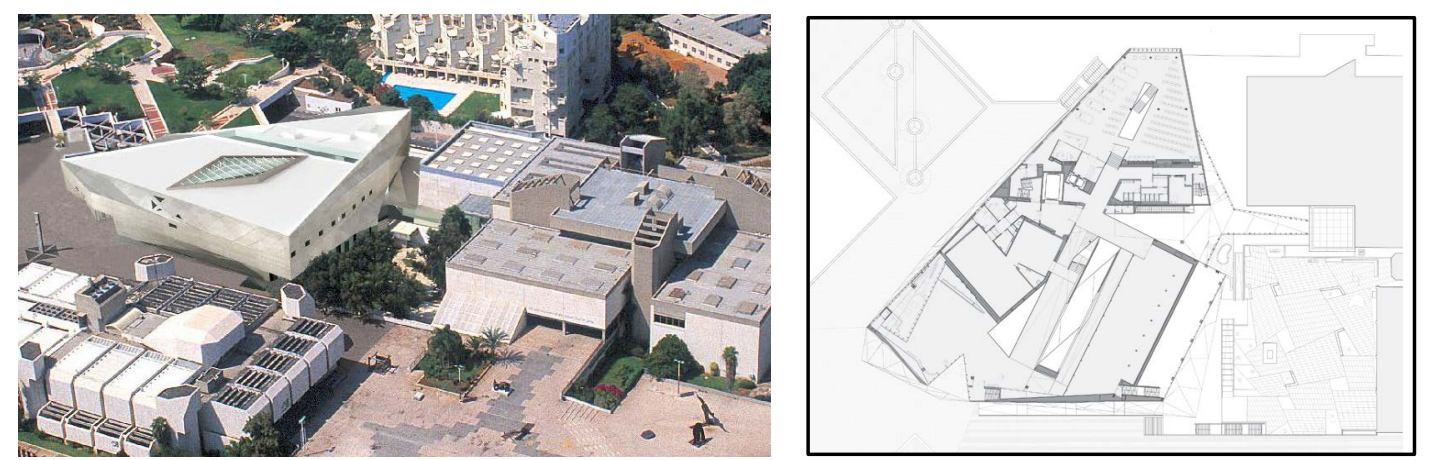

Figure 3. Aerial view of the old museum and the new addition, left; entry level floor plan, right.
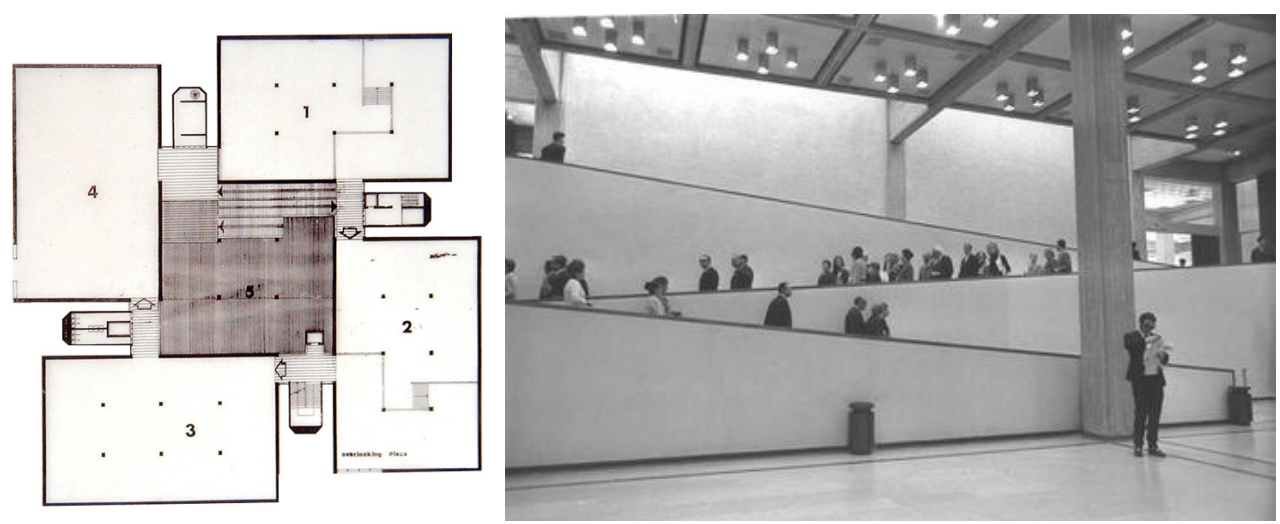

Figure 4. Old museum building by Yashar \& Eytan, 1964-1971: Plan of second floor, left; central atrium, right. 
composed of four rectangular exhibition blocks that are rotated in pinwheel fashion around an atrium. Inside, the reinforced concrete structure has been left exposed as a framing device for the white walls. Its exterior is made of rectangular surfaces cladded with machine-cut stone, which are contrasted with vertical service elements finished with striped concrete.

Since the Tel Aviv Museum was an important agent in rediscovering both Israel's International Style (in an exhibition in 1984) and Brutalism (in a 2001 exhibition), the new building reaffirms the museum's commitment to international modernism. To be convincingly consumed as an image within the mediascape of globalization, the design had to be realized with exactitude and perfection. The challenge of executing the building introduces to the design process a dimension that was latent in previous theoretical projects by Cohen-the predicament generated by having to work within the capabilities and limitations of the local construction industry. How the architect responded to this challenge will be the subject of this study.

\subsection{Local Meaning of Construction}

The process of the museum's construction has been amply documented by the press. The Architectural Record [21] dedicated two separate sections to the construction of the lightfall and the façade, including interviews with the contractor, the structural engineer, and the Israeli architect who collaborated with Scott Cohen. Media accounts ascribed the builders with agency in developing practical solutions for realizing within a constrained budget its abstract, rarefied design, a point reiterated by the architect who asserted that the contractor improved upon his original design. The local media took pride in the successful execution of such a technically demanding work in a country where construction is held in low esteem, especially in comparison with Israel's touted high-tech sector. Thus the story of construction became inseparable from the building's glocal meaning.

The most critical and demanding task for execution was the lightfall, a non-load bearing element made of cast-in-place concrete hyperbolic paraboloids ("hypars") that spirals through the building. Visitors can touch the exposed concrete as they circulate around the atrium, experience the material's tactile qualities, and appreciate the labor invested in preparing the formwork; yet such proximity also makes it impossible to conceal mistakes made during the construction process. Building the atrium required a skilled workforce and a commitment to perfection which were beyond the standards of the Israeli construction industry at the time. During the biding stage, several contractors proposed to realize the atrium with drywall to reduce costs and minimize the employment of skilled labor. Such a technique was previously used in high profile projects such as the Supreme Court Building in Jerusalem by Ada and Ram Karmi (1992). Its vaulted courtrooms and arcaded courtyards referenced Mandate-era monumental architecture designed by British architects and built in traditional masonry techniques. In contrast with original's adherence to the Arts and Crafts ethics of craftsmanship, Karmi's postmodernist building exemplifies Ruskin snotion of "structural deceit" [13], in which one material (drywall) is used to imitate another (masonry vaults). Cohen's insistence on handcrafted, exposed concrete required a high level of workmanship. In the absence of a skilled local workforce, the contractor recruited construction workers from Moldova, an example of how aesthetic choices made by the architect impact the process of construction and the organization of labor. The architect's reference point for insisting on a material whose aesthetic value depends on the quality of labor invested in preparing the formwork is emphatically local:

One of the most critical functions of the "hypars" was thus to commit the museum to a form that would resist the currently popular tendency to import to Tel Aviv the postmodern vocabulary of stone facades typical of Jerusalem. In Israel today, however, cast-in-place concrete has become, for all intents and purposes, taboo. For many, it recalls a "dated" or by-gone era of provincialism and undignified pragmatism [20].

The first reason raised by the architect is that of distinguish Tel Aviv, as a cosmopolitan and secular city, from Jerusalem, the nation's religious center. The client initially asked for a stone façade to confer the museum with an air of monumentality, while the architect promoted a material that resonates more with Tel Aviv's architectural heritage. The second way in which a form can be said to "resist" is related to the status of construction labor. Using cast-in-place concrete counters the tendency to reduce architecture into an immaterial visual image, a pure sign disengaged from the process of its making. In relation to its local context, such a form resists the deskilling of construction work in Israel which has led to the degradation of exposed concrete as a finishing material.

Why concrete and the labor process invested in its casting have fallen into disrepute, and what may be the cultural and political implications of its revival, is examined in the next section. It historicises the local meaning of international architectural styles in relation to the political economy of construction labor. This historical framework complicates the museum's claim to affiliate itself with globalized modernity. 


\subsection{The Political Economy of Construction Labor: A Local History}

This section examines the reciprocal relation between architectural style, state ideology, and construction labor in Israel. Organized in four historical stages, it serves as a context for interpreting the meaning of the building's construction process through the interpretive framework of the glocal.

\subsubsection{Labor Zionism and Modern Architecture}

The making of modernism as the dominant architectural expression of the Zionist Movement is inseparable from its ideology of labor, although this connection is seldom discussed. Zionist thinkers perceived the occupational structure of the Jewish people as distorted and tilted towards unproductive, rent seeking activities such as commerce and finance. In pastoral versions of Zionism, farming was considered to be essential for renewing the bond between the people and the land through the toiling of the soil. Manual trades such as construction were associated with the productive ethos espoused by the founder of the movement, Theodor Herzl. His 1896 blueprint for establishing a state [24] envisioned that a construction army of half a million immigrants recruited from the vast reserves of unemployed Jews will build the state's modern infrastructure, after which the middle and upper classes will immigrate: "By their labour [the unskilled] will gain the right to own their own houses... if they give evidence of good behaviour for a period of three years. In this way we will develop a diligent people who can be readily employed." At the early stages of colonization, Jewish immigrants self-organized to "conquer the work" from the lower cost and more productive native Arab workers. They unionized and established building co-operatives that utilized modern industrial processes and management techniques to increase productivity and monopolize construction activity. The modern architecture of the "White City", and especially the Histadrut Labour Union’s worker's housing estates designed by Bauhaus trained architects, came to represent Labour Zionism, as it was consciously differentiated from vernacular Arab architecture based on artisan labor and locally procured traditional materials.

\subsubsection{Nation Building and Brutalism}

After Israel's independence in 1948, the economic imperative of self-sufficiency and the need to provide incoming immigrants with employment informed a change in the ideology of labor and its architectural expression. To realize the enormous building program of mass housing and civic institutions, the government recruited and trained Jewish immigrants from Arab countries as construction workers, following the belief that "construction acts as a kind of natural vocational school for new immigrants. The majority of new immigrants come from the middle classes and are not accustomed to physical labour... Under such circumstances the construction industry acts as an important and desirable transitional stage” [25]. Reinforced concrete was preferred over steel frame construction because it was locally produced and more labor intensive. In addition, the Histadrut controlled Israel's cement monopoly and owned its largest construction company, Solel Boneh. The architects of that period developed a native version of Brutalism that used exposed concrete as a malleable, modest material to showcase the craftsmanship of unionized, trained labor: the original museum building, designed in 1964 (and built by Solel Boneh), exemplifies of this tendency to endow construction labor with architectural expressivity [26].

\subsubsection{Occupation and Vernacular}

The occupation of Gaza and the West Bank in 1967 had a profound impact on Israel's construction industry. The opening of the local labor market to low-wage, non-unionized Palestinian workers led to the deskilling of construction labor, as there was little economic incentive to invest in vocational training or mechanization. It also facilitated the rise of a neo-vernacular style built with manual stonework. This labor intensive style gave expression to the religious-nationalist sentiments that swept the Israeli public at the time. As for the Brutalist style of exposed, artisanal concrete of the previous decades, it became spurned for its association with the paternalistic Labour Party after it was dethroned in 1977 by the very immigrants it had declassed into manual workers.

\subsubsection{Neoliberalism and Transnational Labor}

The reliance on unskilled, informal, and exploitable Palestinian labor came to an abrupt end with the first Intifada (1987-1993). Added to that, the collapse of the Soviet Union initiated a wave of mass immigration of almost a million Jews. As an emergency measure to resolve the acute labor and housing shortages, the government altered its labor migration policy, permitting contractors to import workers and building materials, a reversal of 
half a century of protectionist economic policy. As a result, by 2006 guest workers made up 26 percent of Israel's construction workforce, well above the norm in other developed countries, and closely resembling employment patterns in the Gulf States [27]. The liberalization of the Israeli economy, boosted by the Oslo Accord (1993), led to unprecedented prosperity that was expressed in neo-modernist and neo-Brutalist style which harked back to Israel's modernist architectural past. The value of this type of architecture resides in the quality of workmanship invested in inexpensive materials. As the skilled workforce for realizing such architecture has long retired, workers were imported from Rumania and Turkey. It could be argued then that the neo-liberal revival of an architectural style that emphasizes expressive, ethical workmanship conflicts with the original ideological meaning of such style as an expression of Labor Zionism.

\section{The Construction Site}

\subsection{The Technical Division of Labor}

The work process that was developed to design and realize the building reflects the dynamics of the glocal. It is typified by a flexible, collaborative organizational structure for coordinating the work of designers, contractors, engineers and construction workers. After winning the competition, the American architect, who did not have a professional license, was paired with a prestigious local firm (Plesner Architects) to adapt the design to local requirements. To fully control the design process, Cohen disengaged from his local partners and established a partnership with Amit Nemlich, a young architect with experience in concrete detailing. Nemlich relocated to America during the design stage, an example of the impact of globalization on labor mobility and flexibility.

Israel Chaskelevitch, the construction manager of the project, likewise modified the working method of his firm [28]. To ensure quality control, most of the work was done in-house rather than outsourced to subcontractors. The international labor force assembled on the construction site included Moldovan master builders, who took the place of Romanian workers after that country joined the European Union in 2007. Other workers skilled in concrete construction came from Turkey, an outcome of a 2003 offset trade agreement in which Turkey's construction expertise was exchanged for Israeli military technology. The workers were recruited by the Turkish construction firm Yilmazlar, as it had a local subsidiary in Israel for building infrastructure projects. This arrangement withstood the 2010 Mavi Marmara incident, in which nine Turkish citizens were killed when the Israeli navy enforced a blockade of the Gaza Strip, leading to the downgrading of diplomatic relationships between the two countries. Lastly, Chinese workers were employed for low-skilled, routine tasks. The next sections examine in detail the construction process of the three elements that define the building's position towards labor and technology: the structure, the lightfall and the façade.

\subsection{Building the Structure}

The construction manager drew a conceptual distinction between construction processes that required unconventional skills and ingenuity, and processes that could be rationalized and realized with existing labour capabilities and construction techniques [28]. While the lightfall and the façade belong to the first type, the structure exemplifies the second. The architect specified Vierendeel trusses (Figure 5) for the structural system to free the art galleries from obstructing structural elements and service ducts, and enabling the rotation of the different levels.
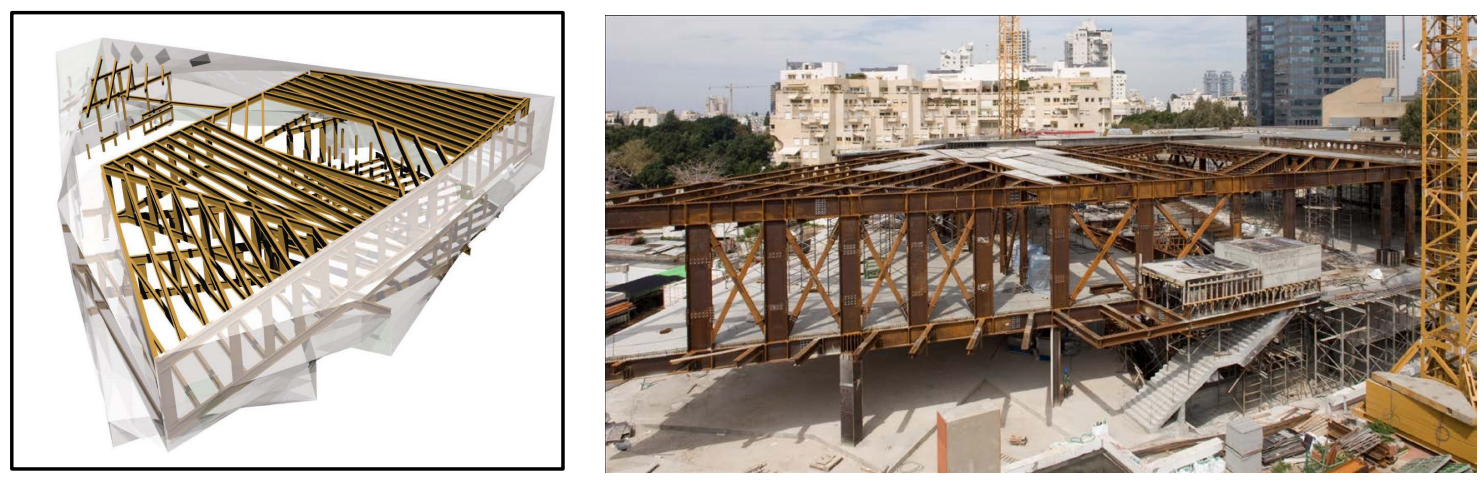

Figure 5. Structural scheme of builiding, left. Assembly of Vierendeel trusses, right. 
The steel structure remains concealed behind drywall throughout the building. It was manufactured in a factory owned by the contractor directly from digital files and transported to the site. The parts were bolted together; manual welding was avoided because its quality could not be assured. Hence the hidden part of the building is its most advanced in terms of applying automated manufacturing techniques to minimize the reliance on skilled work.

\subsection{Building the Lightfall}

The labor process invested in building the lightfall was radically different in terms of skills and work rhythm. The construction of atrium took more than a year, while work elsewhere on the site progressed in a rapid, industrialized pace. The time-consuming work process was dictated by the architect's insistence on exposed cast-inplace concrete and his manipulation of the geometry of the hyperbolic parabola. The basic form of the hypar readily presents itself to rationalized, standardized reinforced concrete construction, as its curved, symmetrical surface is generated by simple, straight lines. Scott Cohen specified twenty-eight different, asymmetrical hyperbolic paraboloids for the atrium. As a result, the lightfall could not becasted with standardized formwork. The architect's insistence on handcrafted, exposed concrete and an irregular design entailed the development of a hybrid work process that merged computerized and artisanal building techniques.

The contractor's engineering staff learned RHINO software in order to translate the complex design into a simplified building process. First, a temporary structure was erected to support the formwork and provide convenient access for the workers. Next, surveyors established four reference points in space for each hypar. These points were manually welded to the scaffolding according to the surveyor's hand communicated instructions (Figure 6). From these points the workers erected an approximates caffold made of metal rods for bracing the wooden framework. Workers were given Excel sheets specifying the varying distances between the rods at each edge of the hypar [29]. According to the construction manager [28], this unconventional work process was devised to minimize the reliance on certified surveyors, who charge the contractor per visit. It also addressed the difficulty of synchronizing the arrival of self-employed professional trades with the work schedule of the contractor, a problem that is endemic on Israeli construction sites.
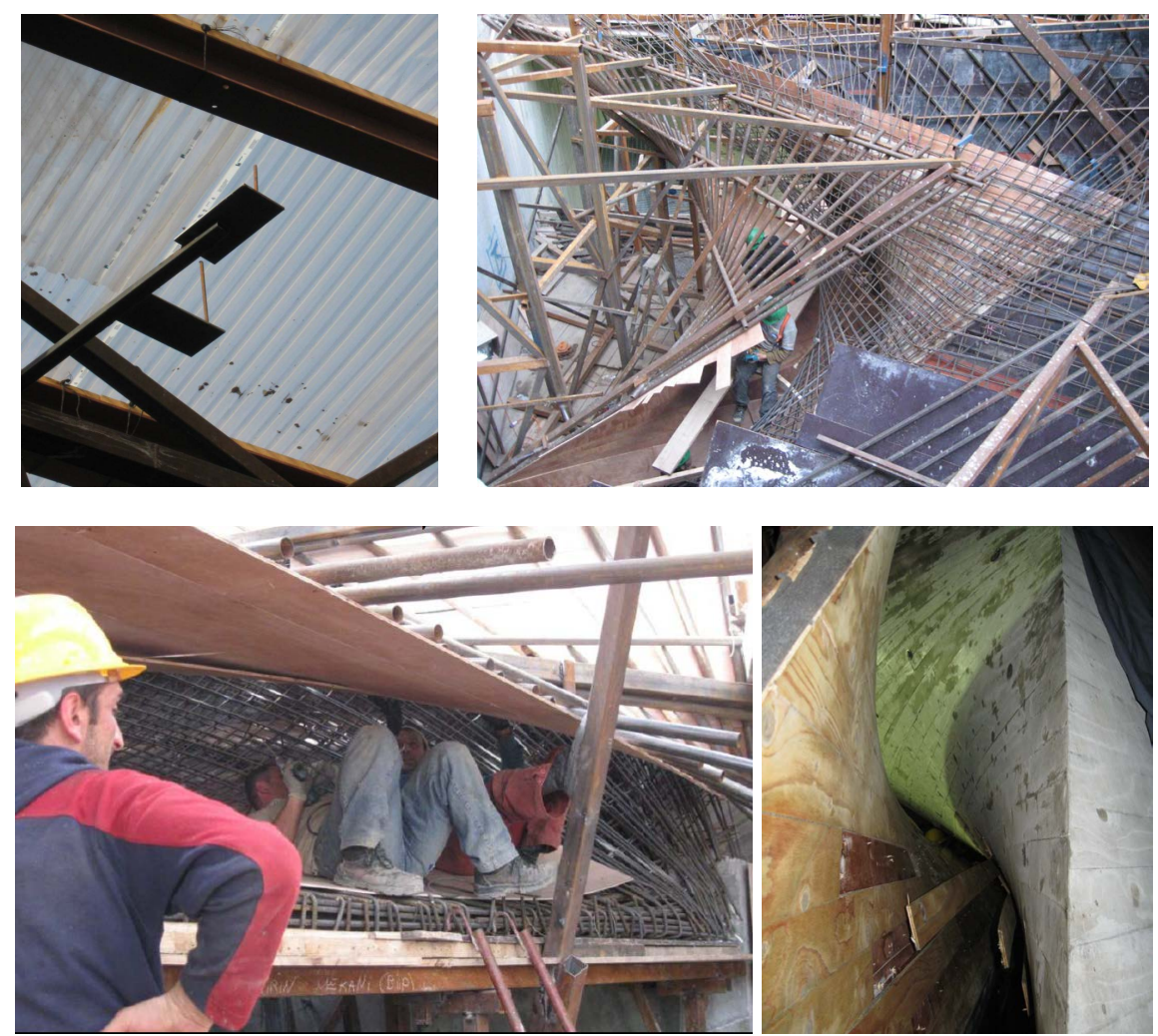

Figure 6. Construction of lightfall. Top: welded reference point for hypar, left; metal pipes for bracing formwork, right. Bottom: workers adjusting formwork, left; concrete after removal of formwork, right. 
The formwork itself was made of spruce planks. Due to the asymmetrical geometry of the hypars, triangular wooden wedges had to be manually cut to fit the irregular gaps between the straight boards. This delicate work was delegated to a crew of experienced craftsmen from Moldova. Thus the construction of the light fall, the element most associated with the bygone Brutalist work ethic, was enabled by the globalization of labor.

\subsection{Building the Façade}

The construction of the facade reveals another level of ambiguity. In the original competition entry, it was envisioned as a smooth hyperbolic surface, but the client insisted on stone cladding to confer the museum with the monumental solemnity associated with Jerusalem. The architect devised a surface composed of a series of flat panels that were subdivided into rectangular stone pieces weighting no more than 60 kilograms to enable manual assembly from a scaffold instead of lifting by cranes [30]. At a later stage, the contractor advanced an alternative finish made of prefabricated concrete panels, and built at his own expense a mock-up to persuade the client of its aesthetic and economic superiority. The architects utilized a parametric script to divide the curvilinear surface into a series of flat geometric shapes. Consequently, the façade was assembled from 465 prefabricated panels, each with its own unique shape.

Unlike the modernist prefabricated element which is standardized in order to facilitate its mass production, the "digital" element is "mass customized". The process developed to manufacture the panels and install them relies on advanced computer technology, yet displays a mode of organization similar to the preindustrial, artisanal workshop. The contractor imported two tilting concrete casting tables for the project. Their size determined the maximum dimension of the panels. Demountable magnetic dams were used to cast the unique shape of each panel. One table was installed at the basement, as the mounting of the panels had to be sequenced from the bottom upward. Once cured, the panels were lifted and moved to their designated storage space using a rail system attached to the ceiling. Onsite manufacturing saved in shipping expenses and minimized damage to the delicate, angular elements [28]. It had another advantage: stockpiling the elements onsite enabled the contractor to disengage the pace of production from that of assembly.

The technique for attaching the irregular panels to the rectangular steel frame epitomizes the hybrid work process developed for building the museum.To accommodate minor inaccuracies in the manufacturing of the panels, the builders devised an internal mediating substructure for attaching them to the steel structure [28]. Computer generated vertical sections of the curved envelop at two meter intervals were fabricated on site from simple metal profiles and welded to the structure. They were calculated to provide at least $7 \mathrm{~cm}$ tolerance for attaching the panels (Figure 7). Still, as many as 5 percent of the panels had to be made from measures taken directly from the empty space they were intended to fit in. The irregular gaps between the panels were filled from the backside with a pre-compressed polyurethane foam sealant, a pliant material that does not require careful workmanship. Unlike the exposed concrete of the light fall, the backside of the façade is never made visible, as it has no craft value. This concealed, rudimentary substructure is emblematic of the hybrid character of the museum's construction process, interspersing digital exactness with manual improvisation.
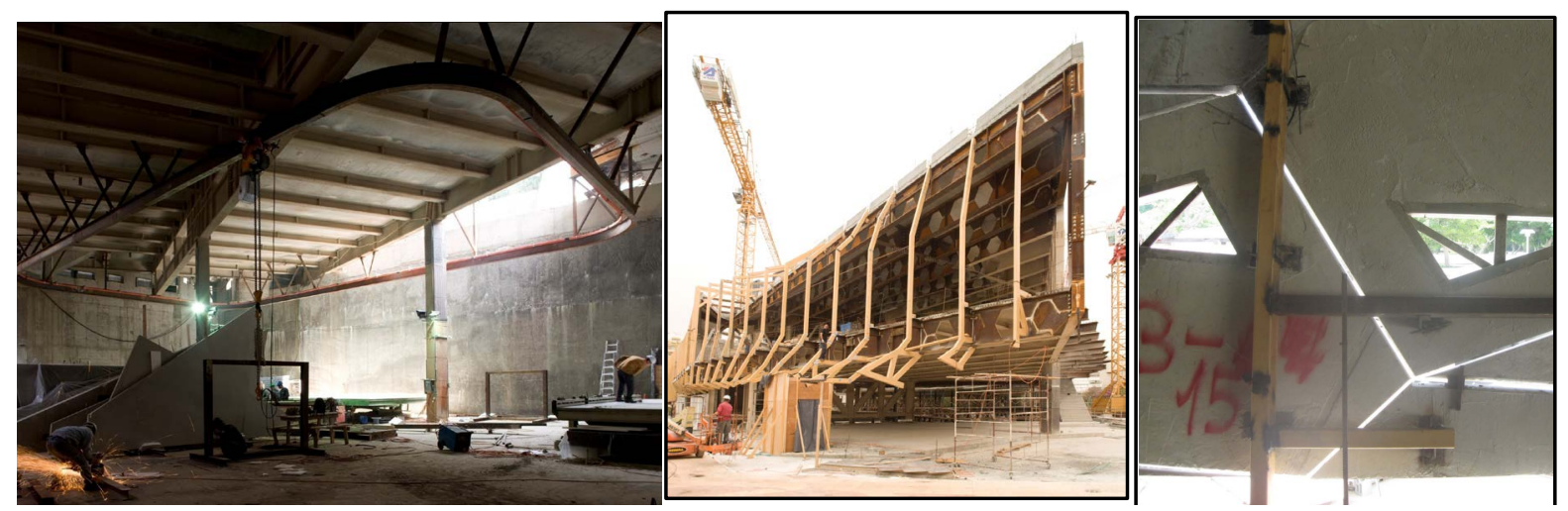

Figure 7. Assembly of façade. Left: tilting casting table and rail suspended from ceiling for manfacturing the panels in the basement. Middle: auxilary frame at two meter intervals; Right: backside of panels welded to the frame prior to sealing. 


\section{Conclusions}

The paper analyzed the construction process of the Tel Aviv Museum's addition as a byproduct of the complex interaction between local and global conditions of production and consumption, and the creative, indeterminate confluence of architectural meaning, technological capabilities, and the political and economic dynamics of construction labor. This interpretive framework is critical of prevailing deterministic accounts that assume a progressive, linear process of technological development. In addition, this methodology is sensitive to the rhetorical function of photographic and textual representation of construction activity within architectural discourse.

Studying the labor of construction in relation to broader tendencies in manufacturing leads to the conclusion that it does not correspond with the deskilling and degradation of construction work theorized by Braverman. The hierarchies between intellectual labor, management, and manual work became dissolved, and workers exercised a high level of control over the pace and method of construction, while expanding their skills in the process. As a result, the building was shaped by the open, reciprocal and creative partnership between different agents, among them architects, the client, the contractor, and the skilled and semi-skilled multinational workforce that was contracted to execute the design. The hybrid work process that brings together advanced computational technologies and traditional modes of craftsmanship is a product of the self-reflexivity of architectural design in respect to the conditions of its production.

To return to the opening question of the essay, it could be argued that the flexibility and agency of construction labor is not inherent to digital architecture as such; rather, it is enabled by the global division of labor, in which modes of organization and skills from different temporalities and localities are combined on site in ambiguous coexistence. This reflects back on the value of construction labor as a meaningful component of the work of architecture. The ethical and phenomenological values commonly associated with craftsmanship are neither universal nor timeless. In the case of the museum, the contemporary revival of craft-based labor is shown to conflict with its original local association with unionized, heroic labor.

\section{Acknowledgements}

An early version of this paper was presented at the EAHN Turin Conference, June 19, 2014. The author wishes to thank the architect Amit Nemlich and the construction manager Israel Chaskelevitch for sharing their invaluable insight.

\section{References}

[1] Sennett, R. (2008) The Craftsman. Yale University Press, New Haven.

[2] Mitchell, W.J. (2001) Roll over Euclid: How Frank Gehry Designs and Builds. In: Gehry, F.O., Ed., Frank Gehry, Architect, Guggenheim Museum Publications, New York, 352-363.

[3] Picon, A. (2004) Architecture and the Virtual: Towards a New Materiality. PRAXIS, 6, 114-121.

[4] Ouroussoff, N. (2011) Chinese Gem That Elevates Its Setting. New York Times, July 5.

[5] Filler, M. (2014) The Insolence of Architecture. New York Review of Books, 61, 10.

[6] Robertson, R. (1995) Glocalization: Time-Space and Homogeneity-Heterogeneity. In: Featherstone, M., Lash, S. and Robertson, R., Eds., Global Modernities, Sage Publications, London, 25-44.

[7] Castells, M. (2000) The Rise of the Network Society. Blackwell, Cambridge.

[8] Appadurai, A. (1996) Modernity at Large: Cultural Dimensions of Globalization. University of Minnesota Press, Minneapolis.

[9] Klingmann, A. (2007) Brandscapes; Architecture in the Experience Economy. MIT Press, Cambridge.

[10] Braverman, H. (1998) Labour and Monopoly Capital: The Degradation of Work in the Twentieth Century. Monthly Review Press, New York.

[11] Bartram, D. (2004) Labor Migration Policy and the Governance of the Construction Industry in Israel and Japan. Politics \& Society, 32, 131-170. http://dx.doi.org/10.1177/0032329204263068

[12] Finkel, G. (1997) The Economics of the Construction Industry. M.E. Sharpe, New York.

[13] Ruskin, J. (1989) The Seven Lamps of Architecture. Dover Publications, New York.

[14] Reichlin, B. (1999) Controlling the Design Process: A Modernist Obsession? Daidalos, 71, 6-21.

[15] Roberts, J. (2007) The Intangibilities of Form: Skill and Deskilling in Art after the Readymade. Verso, London. 
[16] Venturi, R., Brown, D.S. and Izenour, S. (1977) Learning from Las Vegas: The Forgotten Symbolism of Architectural Form. MIT Press, Cambridge.

[17] Frampton, K. (2001) Studies in Tectonic Culture: The Poetics of Construction in Nineteenth and Twentieth Century Architecture. MIT Press, Cambridge.

[18] Ford, E. (2003) The Details of Modern Architecture (Book 1). The MIT Press, Cambridge.

[19] Cohen, P.S. (2001) Contested Symmetries: The Architecture and Writings of Preston Scott Cohen. Princeton Architectural Press, New York.

[20] Cohen, P.S. (2011) The Route to a Building. In: Grobman, Y. and Blonder, A., Eds., Five Moments: Trajectories in the Architecture of the Tel Aviv Museum, Tel Aviv Museum of Art, Tel Aviv, 17-21.

[21] Pearson, C. (2011) A New Spin to the White City. Architectural Record, 72-83.

[22] Curtis, W. (1996) Modern Architecture since 1900. 3rd Edition, Phaidon Press, New York.

[23] Ching, F., Jarzombek, M. and Prakash, V. (2011) A Global History of Architecture. 2nd Edition, John Wiley \& Sons Ltd., Hoboken.

[24] Herzl, T. (1997) The Jews’ State. Jason Aharonson Inc., Northvale.

[25] Drabkin, H.D. (1959) Economic and Social Aspects of Israeli Housing. In: Drabkin, H.D., Ed., Public Housing in Israel, Gadish Books, Tel Aviv, 15-91.

[26] Shiftan, A.N. and Segalovitz, S.S. (2011) The Monumentality of the Everyday. In: Grobman, Y. and Blonder, A., Eds., Five Moments: Trajectories in the Architecture of the Tel Aviv Museum, Tel Aviv Museum of Art, Tel Aviv, 55-67.

[27] Eckstein, Z. (2010) Employment of Foreign Workers. Caesarea Economic Policy Planning Forum, 18, 5-36.

[28] Nemlich, A. (2013) Interview with Author, Tel Aviv, November 19, 2013.

[29] Chaskelevitch, I. (2013) Phone Interview with Author, Tel Aviv, December 20, 2013.

[30] Cohen, P.S. (2006) Elegance, Attenuation, Geometry. In: Rahim, A., Ed., Elegance, Architectural Design, London, 5461. 